\title{
Substance-to-substance joining of quartz glass
}

\author{
Steffen Dahms ${ }^{\mathrm{a}}$, Priit Kulu ${ }^{\mathrm{b}}$, Renno Veinthal ${ }^{\mathrm{b}}$, Ursula Basler ${ }^{\mathrm{a}}$ \\ and Sabine Sändig ${ }^{\mathrm{a}}$ \\ a Günter-Köhler-Institut für Fügetechnik und Werkstoffprüfung GmbH, Otto-Schott Str. 13, 07745 \\ Jena, Germany; \{sdahms, ubasler, ssaendig\}@ifw-jena.de \\ b Tallinn University of Technology, Department of Materials Engineering, Ehitajate tee 5, 19086 \\ Tallinn, Estonia; \{priit.kulu, renno.veinthal\}@ $@$ ttu.ee
}

Received 17 September 2008, in revised form 24 March 2009

\begin{abstract}
A pioneering procedure for substance-to-substance joining of quartz glass is described. Diffusion welding was examined as a possible joining method. Welded components made of quartz glass are applied in high-temperature engineering for laser and optics applications. Quartz glass was joined without interlayers in order to maintain optical characteristics of the joining partners. Based on the principles of joint formation of pure $\mathrm{SiO}_{2}$-glass in the solid state, a joining technology, using diffusion welding, is described and the joints are analysed. Diffusion welding, realized at near-transformation temperature, results in an increase of polymerization and formation of an optical thin joining layer.
\end{abstract}

Key words: quartz glass, diffusion welding, thermal expansion, substance-to-substance joint, optical quality.

\section{INTRODUCTION}

Diffusion welding is a procedure for joining materials in the solid state without molten phase. This procedure is mainly used to join metals where diffusion processes and dislocations in the crystalline structure lead to a substance-tosubstance joint.

Diffusion welding has mainly been used in the field of armament and tool making since the 1950s and today it provides solutions for complicated welding tasks in the aviation and aerospace industry, nuclear energy technology, optical industry and in microsystem technology. Numerous joining tasks can be performed by means of this procedure to join parts of the same material. Presently diffusion welding represents an interesting approach to joining metals, glasses, ceramics, and different ceramics with each other in spite of different character- 
istics of the materials. A contact of the surfaces to be welded is necessary for the joining process. A joint is formed by surface diffusion and material reactions, which are caused by heat and pressure applied in a suitable work medium.

Diffusion welding enables the production of temperature resistant, highstrength and vacuum-tight joints. An advantage of diffusion welding is that no interlayers (solders) are necessary. That is why this procedure is interesting for joining of glasses as the optical qualities are maintained and the joining zone remains transparent.

Quartz glass is an inordinate network of $\mathrm{SiO}_{4}$-tetrahedrons, which are connected at their $\mathrm{O}^{2-}$ corners (4-bridge oxygen ions) $\left.{ }^{1}\right]$. The following theoretical considerations, based on welding experiments, speak in favour of the diffusion welding of glass. They are also meant to be the basis for the diffusion welding of technical and optical glasses, crystals and glass ceramics, which can be used for interesting technical applications due to their versatile characteristics.

The aim of the joining process is to create a substance-to-substance joint, no matter which procedure has been used. Due to the extent of their bonding energy, atom, ion, metal and mixed bonding types are counted among the bondings, which enable the creation of a substance-to-substance joint, because their bonding energy is at least as high as that of the actual base material. The van-derWaals bonding is much weaker and would not create a substance-to-substance joint $\left[^{2-4}\right]$.

From literature, different hypotheses for the joint creation in the diffusion welding process are known, such as the thin layer, energy, recrystallization, diffusion and gap hypotheses $\left[{ }^{5,6}\right]$. Studies on the joining of other material pairs have shown that these hypotheses cannot describe the processes adequately, because they are restricted by respective material combinations. Even though the lack of adequate experimental data complicates kinetic considerations of the reactions and thermodynamic predictions on the possibility of the joint, assessments by means of thermodynamic laws are possible.

When heating two contacting solid surfaces, a viscous flow starts at a sufficiently high temperature and pressure. With glasses, temperatures near the transformation temperature $\left(T_{\mathrm{g}}\right)$ are necessary. In this process the surface layers as well as some amount of the base material are torn apart. Diffusion processes (gap formation and movement) take place on the surfaces or in the bodies. The welding surfaces conform to each other until the state of physical contact is achieved. This is caused by the van-der-Waals interaction. This process takes a certain time depending on the temperature, contact pressure per unit area and the condition of the material and its surface. Free valencies, so-called activated centres, occur on the surface as solid body surfaces are always heterogeneously reactive $\left[^{7-9}\right]$.

For substance-to-substance joints the activation energy $\left(E_{\mathrm{a}}\right)$ has to be applied until chemisorption processes start in the activated centres. Then clusters or germs are formed in these areas between the surfaces and thus the substance-tosubstance joint is created. In the transition of the physical contact chemisorption, a further approximation of the surface atoms takes place. If afterwards clusters or 
germs are formed, these substance-to-substance joint islands can grow through further energy input and subsequent diffusion processes at the surface. More and more atoms react with each other. A surplus of energy can lead to volume diffusion processes afterwards.

The diffusion welding of quartz glass can be considered as a joining of lowmolecular $\mathrm{Si}_{\mathrm{x}} \mathrm{O}_{\mathrm{y}}$ tetrahedron structures to form higher-molecular $\mathrm{Si}_{\mathrm{x}} \mathrm{O}_{\mathrm{y}}$ clusters. This process takes place in a mutually formed interlayer of the quartz glass surfaces. At low temperatures, $\mathrm{H}_{2} \mathrm{O}$ - and $\mathrm{OH}$-groups function as catalysts. Condensation reactions are exothermal, the formation of larger clusters is abetted, especially in the formation of cristobalite-containing networks $\left[{ }^{10}\right]$.

Movements of tetrahedron chains and tetrahedron rings in the interlayer are primary processes in the diffusion welding. Rising temperature leads to increased movability of the $\mathrm{Si}_{\mathrm{x}} \mathrm{O}_{\mathrm{y}}$ structures and also individual $\mathrm{H}_{2}$ and $\mathrm{OH}$ molecules as well as to the desorption of $\mathrm{H}_{2} \mathrm{O}$ and $\mathrm{OH}$. Thus the probability of condensation rises. When the temperature rises, the low-molecular elements remain an important reaction partner due to their higher movability.

From a temperature of $320^{\circ} \mathrm{C}$, the original number of silanol places is no longer available due to irreversible condensation reactions. $\mathrm{H}_{2} \mathrm{O}$ molecules are unable to break the higher-molecular clusters. At about $400^{\circ} \mathrm{C}$, all $\mathrm{H}_{2} \mathrm{O}$ molecules are desorbed from the interlayer, and gluing is physically not possible. However, this temperature is sufficient for a substance-to-substance joining of quartz glass samples, physically glued at an area of $15 \times 15 \mathrm{~mm}^{2}$, if these are tempered for $60 \mathrm{~h}$, exposed to air.

At diffusion from the pore volumes at a temperature higher than $500^{\circ} \mathrm{C}, \mathrm{H}_{2} \mathrm{O}$ is important for diffusion welding. Single silanol bridges are broken and the number of $\mathrm{OH}$-groups is increased. Main reactions take place between clusters without surface groups. This is caused by the welding pressure, applied at a temperature of $950^{\circ} \mathrm{C}\left[{ }^{11}\right]$. Here the reaction layer grows with the rising temperature. Movements and growing processes of the $\mathrm{Si}_{\mathrm{x}} \mathrm{O}_{\mathrm{y}}$ grains at the surface are the reason for this. Only high-molecular $\mathrm{Si}_{\mathrm{x}} \mathrm{O}_{\mathrm{y}}$ clusters without $\mathrm{OH}$-surface groups and $\mathrm{SiO}_{2}$ christobalite structures can be expected after the complete transformation of the silanol groups at temperatures above $900^{\circ} \mathrm{C}$. The transformation of silica gels takes place at about $1100^{\circ} \mathrm{C}$. This enables a drastic reduction of the welding time. The formation of a thin translucent connection layer of $\mathrm{SiO}_{2}$-like $\mathrm{Si}_{\mathrm{x}} \mathrm{O}_{\mathrm{y}}$ clusters (high-temperature $\beta$ - or low-temperature $\alpha$-cristobalite $\mathrm{SiO}_{2}$ ) between diffusion-welded quartz glasses and the complete polymerization of neighbouring $\mathrm{Si}_{\mathrm{x}} \mathrm{O}_{\mathrm{y}}$ structures as well as an increase of bridge oxygen ions take place simultaneously $\left[{ }^{12}\right]$.

Despite the use of the diffusion welding for substrate-to-substrate joining of different materials $\left[{ }^{13-14}\right]$, the joining process of technical and optical glasses without interlayers, in order to maintain optical characteristics of joints, has not been studied in detail. In this paper the diffusion welding of quartz glass has been studied in order to optimize process parameters and to evaluate the optical parameters of the formed joining zone. 


\section{EXPERIMENTAL}

Quartz glass, which is high-temperature stable and chemically resistant, was used in order to examine the joining mechanisms that lead to a substance-tosubstance joint in the diffusion welding process. Quartz glass joints were made and the joining procedure was evaluated. The creation of the joining zones was characterized by their properties.

The procedure is generally characterized as joining solid state parts as a result of the occurrence of atomic bonds, created through local plastic deformations at an increased temperature and mutual diffusion in the surface layers. In the preparation of the diffusion welding trials it was necessary to process the welding surfaces of the quartz glasses by grinding and polishing. The demands on the contact surfaces of the quartz glasses were very high in terms of contour parallelism, roughness and cleanliness in order to realize high-quality joints. Therefore the joining surfaces of the quartz glass samples with a diameter of $20 \mathrm{~mm}$ and a thickness of $6 \mathrm{~mm}$ were processed by lapping with silicon carbide (SiC) and different grain sizes from 37 to $5 \mu \mathrm{m}$ and subsequent polishing on a lever polishing machine with Ceroxid $\left(\mathrm{CeO}_{2}\right)$, a polishing paste of $1 \mu \mathrm{m}$. Surface processing resulted in an average roughness of $0.02 \pm 0.01 \mu \mathrm{m}$. Figure 1 shows a scan over a polished quartz glass surface.

Based on the chemical and physical qualities of quartz glass (Table 1), the welding temperature, welding time and welding pressure were varied. For the welding process itself, the following conditions for the diffusion welding of the same glasses as well as of different glasses with each other are to be considered:

- minimal difference of the expansion coefficients $\Delta \alpha$ (glass 1/glass 2 ) $\leq$ $0.3 \times 10^{-6} / \mathrm{K}$;

- the same transformation temperatures $T_{\mathrm{g}}$, or the welding process conforms with the lowest transformation temperature of the glass combination;

- thermal conductivity of the glasses;

- compatible geometry of the joining surfaces for diffusion welding;

- high demands on the surface topography and plane parallelism of the welding surfaces $\left[{ }^{11}\right]$.

The diffusion welding of the glasses was carried out in a vacuum/inert gashigh temperature furnace with an integrated vertical press capacity device (Fig. 2). The contact pressure per unit area on the welding material remained constant during the entire welding process. The use of a ball joint between the plunger and the welding material has proven advantageous in order to guarantee a close contact of the welding surfaces. This leads to an equal pressure over the whole welding surface. A smooth heating of the whole glass volume minimizes tensions in the glass body. The thermal finishing treatment is not necessary (cooling process).

The diffusion welding trials of quartz glass were carried out identically. The surfaces to be joined were cleaned with a mixture of ethanol and ether (ratio $60: 40)$ immediately before the joining trials. Then the furnace was evacuated and 
Table 1. Characteristics of quartz glass

\begin{tabular}{|c|c|c|c|}
\hline \multirow[t]{2}{*}{ Qualities } & \multicolumn{3}{|c|}{ Parameters } \\
\hline & $n_{\mathrm{o}}$ & $n_{\mathrm{e}}$ & $\lambda$ \\
\hline & 1.6775 & 1.6899 & $185 \mathrm{~nm}$ \\
\hline & 1.5709 & 1.5809 & $325 \mathrm{~nm}$ \\
\hline & 1.5482 & 1.5575 & $508 \mathrm{~nm}$ \\
\hline & 1.5423 & 1.5513 & $644 \mathrm{~nm}$ \\
\hline & 1.5201 & 1.5282 & $2.05 \mu \mathrm{m}$ \\
\hline & 1.4995 & 1.5070 & $3.00 \mu \mathrm{m}$ \\
\hline Density & \multicolumn{3}{|c|}{$2.648 \mathrm{~g} / \mathrm{cm}^{3}$} \\
\hline Transformation temperature $T_{\mathrm{g}}$ & \multicolumn{3}{|c|}{$1100-1120^{\circ} \mathrm{C}$} \\
\hline Softening temperature & \multicolumn{3}{|l|}{$1655^{\circ} \mathrm{C}$} \\
\hline Thermal conductivity & \multicolumn{3}{|c|}{$1.4 \mathrm{~W} /(\mathrm{m} \mathrm{K})$} \\
\hline Special heat capacity & \multicolumn{3}{|c|}{$787 \mathrm{~J} /(\mathrm{kg} \mathrm{K})$ at $25^{\circ} \mathrm{C}$} \\
\hline Thermal expansion $\alpha$ & \multicolumn{3}{|c|}{$5 \times 10^{-7} / \mathrm{K}$} \\
\hline Hardness (Knoop) & \multicolumn{3}{|c|}{461 at $200 \mathrm{gf}, 741$ at $500 \mathrm{gf}$ proof load } \\
\hline Elasticity modulus $E$ & \multicolumn{3}{|c|}{$76.5 \mathrm{GPa} \_\_\mathrm{Y}, 97.2 \mathrm{GPa} \| \mathrm{Y}$} \\
\hline Shear modulus $G$ & \multicolumn{3}{|c|}{$36.4 \mathrm{GPa} / 57.13 \mathrm{GPa}$} \\
\hline Solubility in water & \multicolumn{3}{|c|}{ Insoluble } \\
\hline Crystalline structure & \multicolumn{3}{|c|}{ Monocrystal } \\
\hline
\end{tabular}

(a)

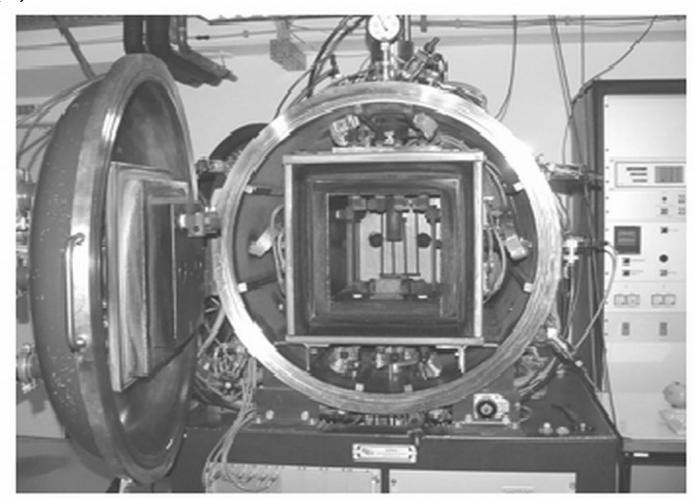

(b)

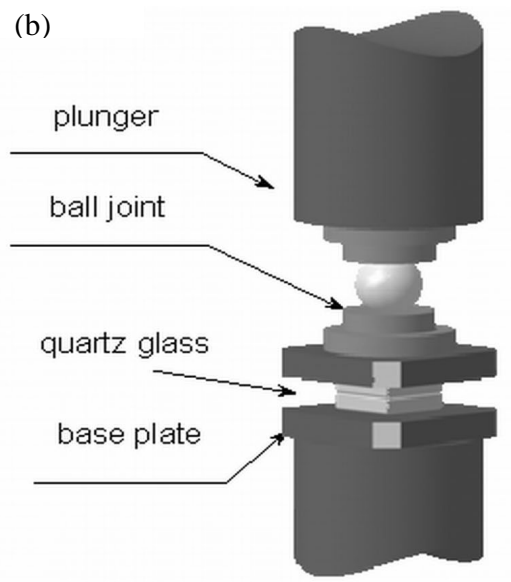

Fig. 2. Diffusion welding equipment (a) and scheme of compression loading of the to be joined quartz glass parts (b).

after reaching a fore-vacuum of about $10^{-1} \mathrm{mbar}$, the respective temperaturetime-force parameters (welding parameters) previously programmed via software were started automatically. Generally the temperature cycle of the regime can be divided into three phases:

- heating phase;

- welding phase with ongoing diffusion processes;

- cooling phase. 
Table 2. Diffusion welding parameters of quartz glass

\begin{tabular}{c|c|c}
\hline $\begin{array}{c}\text { No of the } \\
\text { experiment }\end{array}$ & $\begin{array}{c}\text { Welding temperature, } \\
{ }^{\circ} \mathrm{C}\end{array}$ & $\begin{array}{c}\text { Welding time, } \\
\mathrm{h}\end{array}$ \\
\hline 1 & 800 & 2 \\
2 & 900 & 2 \\
3 & 1000 & 2 \\
4 & 1050 & 2 \\
5 & 1100 & 2 \\
6 & 1100 & 6 \\
7 & 1100 & 11 \\
8 & 1100 & 12
\end{tabular}

Based on the theoretical considerations of solid body reactions on pure $\mathrm{SiO}_{2}$-glass surfaces, welding was carried out and analysed in a temperature range of $800^{\circ} \mathrm{C}$ near the transformation temperature of the quartz glass $\left(1100^{\circ} \mathrm{C}\right)$ with welding pressure $2000 \mathrm{~N}$. The welding times were varied, but the welding pressure remained constant $10^{-1}$ mbar (Table 2 ). In the heating phase the evacuated and compression-loaded samples were heated to the respective welding temperature with a medium heating gradient of $<10 \mathrm{~K} / \mathrm{min}$. The samples to be joined were kept at the welding temperature over a defined time interval after which the formation of the joint happened. The cooling phase started immediately after the welding phase with an average cooling rate of $<10 \mathrm{~K} / \mathrm{min}$ down to the room temperature.

The quality of the welding joint formation was visually checked. If the joint was not completely formed, Newton rings could be recognized in the glass joint. For measuring the transmission and stress birefringence in transparent joints, a multi-purpose epitaxial in-situ monitor EpiRAS-Mapper was used. The local internal transmission, the stress-induced phase shift and the direction of the relative strain were measured.

To estimate the optical properties of diffusion welded quartz glass joints, transmission and reflection of them were studied using optical spectrometer in the low infrared range (FIR, number of waves $400-10 \mathrm{~cm}^{-1}$, wavelength $25-1000 \mu \mathrm{m}$ ).

\section{RESULTS AND DISCUSSION}

By visual examination of welded joints the Newton rings are visible. They occur due to the interference of light reflected from the welded surfaces, due to the gap between the welding surfaces in the nm range (Fig. 3). The results of visual examination are given in Table 3.

In further joining trials, by diffusion welding of the quartz glass in the range of the transformation temperature $\left(T_{\mathrm{g}}=1100^{\circ} \mathrm{C}\right)$ and at welding pressure $2000 \mathrm{~N}$, welding time was varied. Ultrasonic investigations were carried out at welding times 2, 6, 11 and $12 \mathrm{~h}$ (Fig. 4). The ultrasonic images show the quality of the joint formation depending on the welding time. After $6 \mathrm{~h}$ only partial joints in the border area were recognizable. The relatively weak bonding mechanisms are 


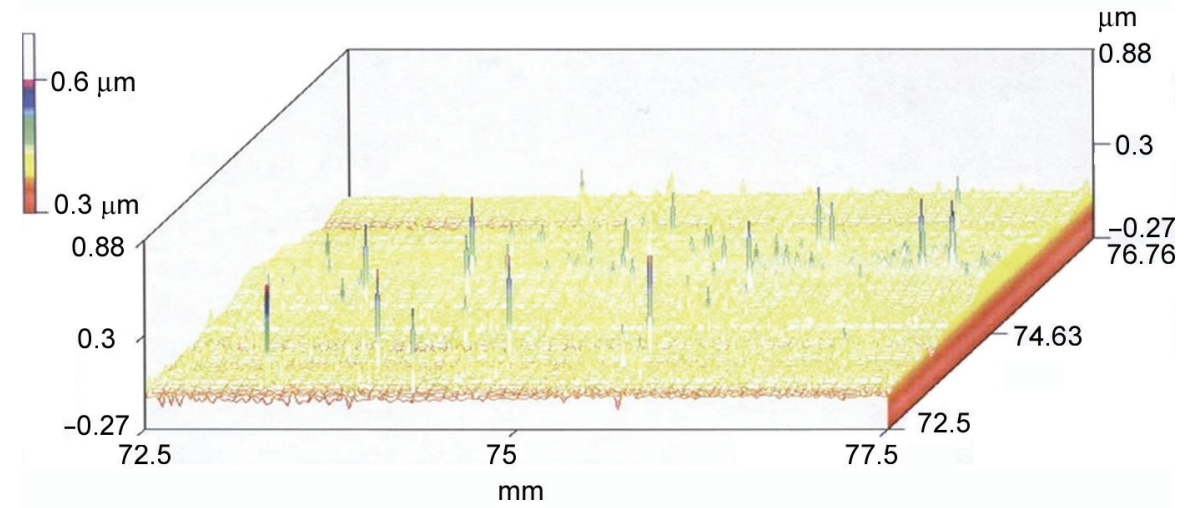

Fig. 1. Topography of a polished quartz glass surface.

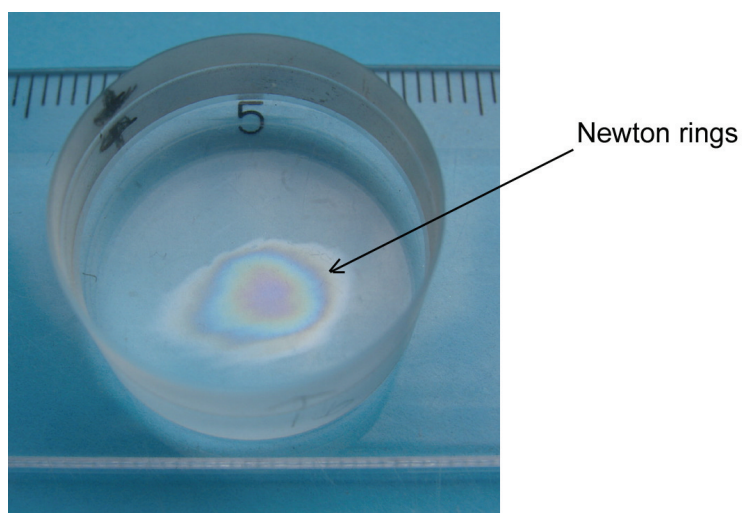

Fig. 3. Example of a welded joint with Newton rings. 
(a)

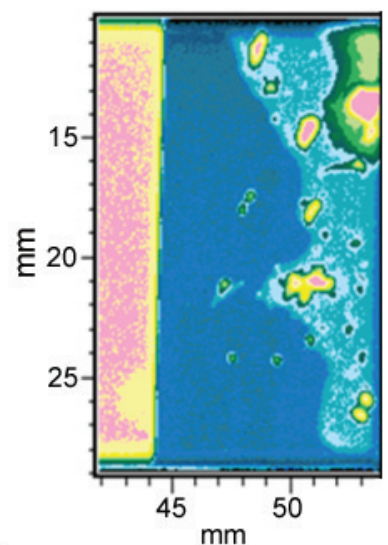

(b)

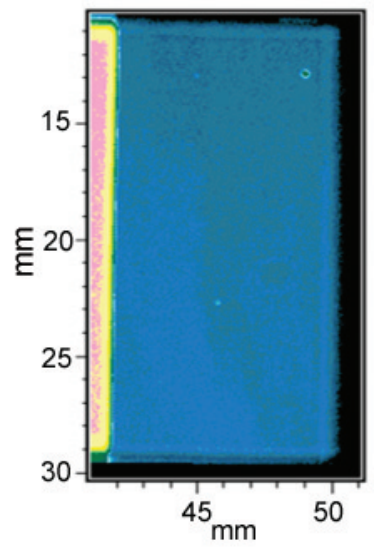

(c)

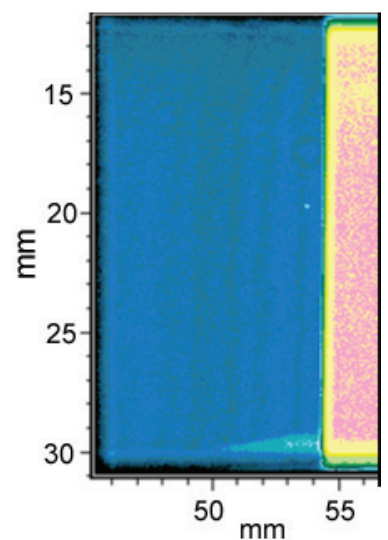

Fig. 4. Ultrasonic scans of the joints at the welding time: $a-6 h, b-11 h$ and $c-12 h$ at a welding temperature of $1100^{\circ} \mathrm{C}$.

(a)

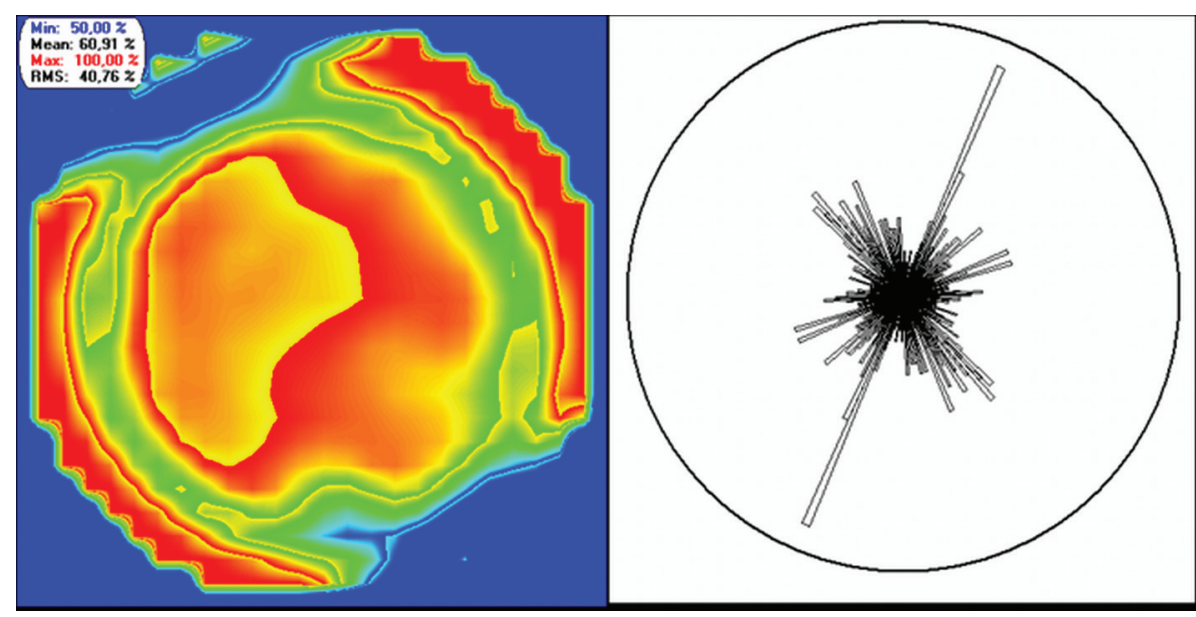

Fig. 6. Optical behaviour of the quartz glass joint: $a-$ transmission, $b-$ texture rose. 
Table 3. Diffusion welding results of quartz glass

\begin{tabular}{c|l}
\hline No of the experiment & Welding result \\
\hline 1 & No joint \\
2 & No joint \\
3 & No joint \\
4 & Newton rings \\
5 & Newton rings \\
6 & Newton rings \\
7 & Optimal joint \\
8 & Optimal joint
\end{tabular}

mainly due to the adhesion and mechanical anchorage and simultaneously reduce the stability of the joint. The prolongation of the welding time led to more homogeneous welding surfaces. An extensive formation of clusters was observed depending on the welding time as described in the theory of the joining mechanism. The result was a substance-to-substance joint.

Investigations with a scanning electron microscope illustrate the result more clearly. Welding samples were investigated for welding times of 2 and $12 \mathrm{~h}$ (Fig. 5). Figure 5a shows an incomplete and only partially formed joining zone, whereas in Figure $5 \mathrm{~b}$ a complete, crack-free and homogeneous joining zone can be seen. The boundary layer has completely vanished and a compact quartz glass body has formed.

With diffusion-welded materials, the joining layer is a discontinuity in the material structure. It is characterized by a deviant optical behaviour compared with the non-welded material. The transmission or the stress birefringence in the whole joining area determine the degree of homogeneity of the welded joint. Optimally joined areas are expected to show only low transmission losses, whereas non-welded or badly joined areas are characterized by higher intensity losses due to reflection and light scattering. A diffusion-welded quartz glass joint was investigated (joining area $\varnothing=20 \mathrm{~mm}$, thickness $10 \mathrm{~mm}$ ). Figure 6 shows

(a)

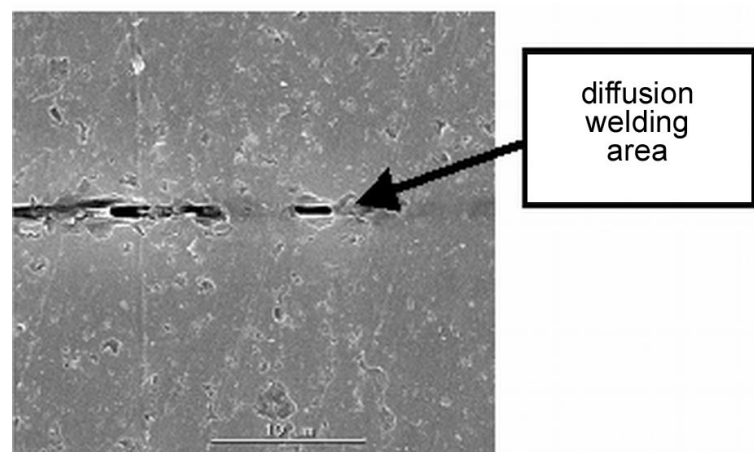

(b)

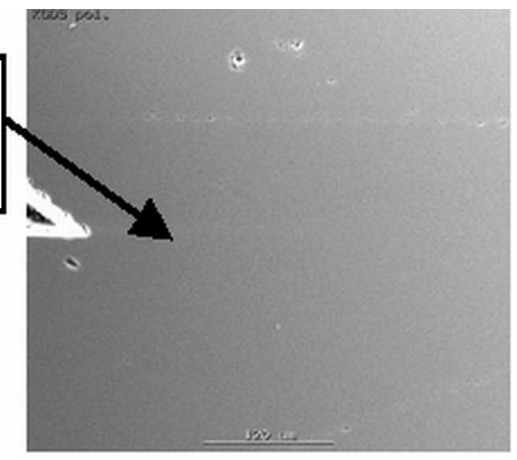

Fig. 5. SEM images of the joining zone at the welding time: $a-2 h, b-12 h$ at a welding temperature of $1100^{\circ} \mathrm{C}$. 
that the central area has been welded well and the quality of welding becomes worse towards the edge region.

The central area shows uniform transmission. The joint in the edge region is worse. RED represents $100 \%$, whereas GREEN indicates $75 \%$ of transmission (Fig. 6a). Fine structures in the edge region are characterized by the Newton rings. The reason for the joining that is worse in the edge region is trimming, which is typical for optical surfaces. This explanation is supported by the very symmetrical and even shape. The directions preferred are hardly recognizable in the texture rose (Fig. 6b). This is typical for a homogeneously cooled glass. Measurement of the transmission and reflection of a welded quartz glass joint also prove this result (Fig. 7). Hardly deviating reflection or diffusion losses could be detected in the measured wavelength range. The small differences in the transmission graph (1st joining) of 50 to $2200 \mathrm{~nm}$ are due to the greater thickness of the reference sample.

Figure 8 shows an example of a diffusion-welded component for optical precision engineering.

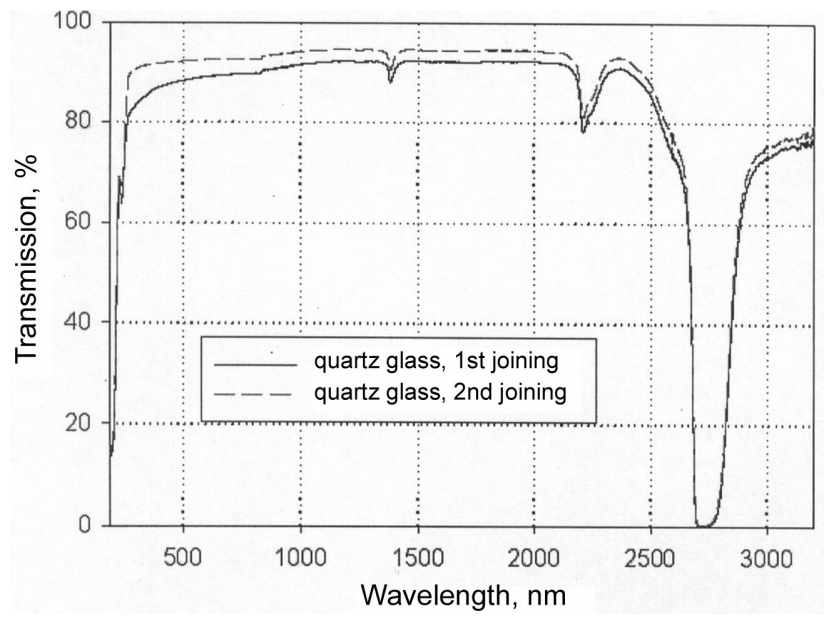

Fig. 7. Transmission graph of quartz glass joints.

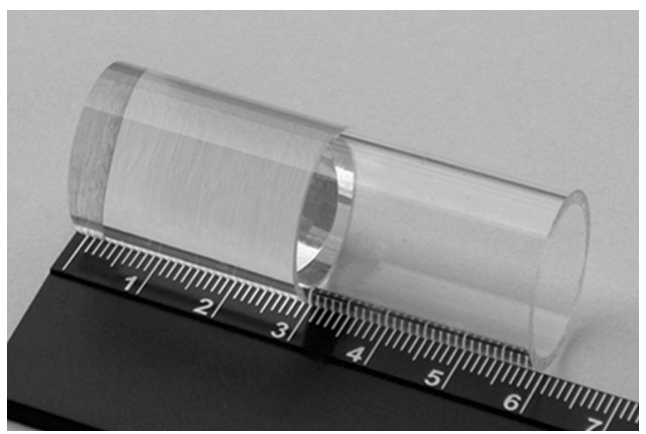

Fig. 8. Diffusion-welded quartz glass component of an optical system. 


\section{CONCLUSIONS}

The procedure to be applied for the substance-to-substance joining of glass was investigated. Pure $\mathrm{SiO}_{2}$ glass (quartz glass) was tested for this purpose. Welding trials have shown that substance-to-substance joints can be realized at near-transformation temperature depending on the welding times. The reason for that is an increased polymerization of neighbouring $\mathrm{Si}_{\mathrm{x}} \mathrm{O}_{\mathrm{y}}$ structures at a temperature above $900^{\circ} \mathrm{C}$. An optical thin joining layer is formed between the welding surfaces by the formation of high-molecular $\mathrm{Si}_{\mathrm{x}} \mathrm{O}_{\mathrm{y}}$ clusters without $\mathrm{OH}$ surface groups and by complete transformation of the silanol groups. Investigations with a scanning electron microscope as well as optical measurements on the quartz glass joints have proved the result. A substance-to-substance joint could be realized, which does not differ from the initial glass in terms of its qualities. The result is a high-quality material joint. High stability and vacuum tightness in the ultra-high vacuum range could be proven. No deformation of glass was observed at diffusion welding at the transformation temperature. The long welding time of up to $12 \mathrm{~h}$ guarantees low stress in the material. The results of the investigations were used in concrete applications.

In future, diffusion welding is prospective to be applied to other glasses, glass ceramics and crystals. First investigations of the welding of borosilicate glasses and low-expansion glass ceramics (Ceran or Zerodur) were successful. The investigations have shown that glasses, consisting of several chemical components, reduce the welding time drastically. Further investigations on the joint formation have to be carried out and analysed.

\section{ACKNOWLEDGEMENTS}

This study has been financed by Forschungsvereinigung des DVS, AiF Nr.: 13.331 B/DVS-Nr.: 5.024 and BMWi Programm INNO-WATT - FuEProjekt Reg.-Nr. 1089/03, Germany. This work was also supported by the targeted financed project No. SF 0140091s 08, funded by the Ministry of Education and Science of Estonia.

\section{REFERENCES}

1. Steil, H. Röntgenbeugungsuntersuchungen zur Nahordnungsstruktur verschiedener Kieselgläser. Mitt. Vereinigung Kristallographie, Berlin, 1981, 16, 4-25.

2. Basler, U., Knepper, P., Reisgen, U. and Wiesner, P. Gegenwärtiger Stand und Zukunftsaussichten der Sonderschweißverfahren - Teil 3: Diffusionsschweißen. Schweissen und Schneiden, 2003, 55, 28-30.

3. Madry, C., Basler, U. and Köhler, G. Diffusionsschweißen temperaturempfindlicher Werkstoffe über Zwischenschichten. Schweissen und Schneiden, 2001, 53, 736-739.

4. BMWi AiF-Projekt - Kristalle. Fördernummer 13.331 B - Günter-Köhler-Institut für Fügetechnik und Werkstoffprüfung GmbH, 2004. 
5. Metelkin, P. A., Pavlova, U. A. and Pozdeeva, N. V. Welding of Ceramics and Metals. Metallurgiya, Moscow, 1977 (in Russian).

6. Mazur, A., Al'ekhin, V. P. and Shorshorov, M. H. Processes of Welding and Brazing in Manufacturing of Semiconductive Devices. Radio and Television, Moscow, 1981 (in Russian).

7. Weissmantel, Ch. and Hamann, C. Grundlagen der Festkörperphysik. VEB Deutscher Verlag der Wissenschaften, Berlin, 1979.

8. Schwabe, K. Physikalische Chemie. Akademie-Verlag, Berlin, 1973.

9. Engels, S. Anorganische Festkörperreaktionen. Akademie-Verlag, Berlin, 1981.

10. Dunken, H. H. and Hoffmann, R. Quantenchemische Berechnungen von $\mathrm{SiO}_{2-}$ Oberflächenclustern und ihren Adsorptions- und Oberflächenreaktionen. Z. Phys. Chemie NF, Wiesbaden, 1981, 125, 207-238.

11. Ghita, C. and Githa, L. Hardening of quartz optical contact by thermal treatment. Rev. Sci. Instr., 1972, 43, 1051-1052.

12. Eitel, W. Silicate Science. Vol. 1 Silicate Structures. Academy Press Ltd., New York, London, 1964.

13. Dahms, S., Basler, U. and Köhler, G. Substance-to-substance joining of crystals, glasses and glass ceramics. In Abstracts 15th International Baltic Conference on Engineering Materials \& Tribology-Baltmattrib 2006. Tallinn, 2006, 46.

14. Dahms, S., Basler, U. and Köhler, G. Diffusion welding - an alternative joining procedure, chances and limitations for exemplary applications. In Proc. 1th South-East European Welding Congress; Welding and Joining Technologies for a Sustainable Development and Environment. Timisoara, Romania, 2006, 203-211.

\section{Kvartsklaasi difusioonliitmine}

\section{Steffen Dahms, Priit Kulu, Renno Veinthal, Ursula Basler ja Sabine Sändig}

Artiklis on vaatluse all kvartsklaasi difusioonkeevitus. Difusioonkeevitatud kvartsklaastooted leiavad kasutamist kõrgetemperatuurses lasertehnikas ja optikas. Kvartsklaasist detailid ühendati ilma vahekihtideta, säilitamaks saadava liite põhilised optilised näitajad. Tulenevalt puhta räniklaasi liidete formeerumise põhimõtetest tardolekus uuriti kvartsklaasi difusioonliitmistehnoloogiat ja saadava liite omadusi. Difusioonkeevitus viidi läbi faasimuutuse temperatuurile (klaasistumistemperatuurile $1100-1120^{\circ} \mathrm{C}$ ) lähedastel temperatuuridel, mis tagas kiire polümerisatsiooni ja õhukese optilise liitekihi moodustumise. 